\title{
Investigation of Factors Affecting Consumer Behaviors Before Purchase: A Research on Instagram Shoppers
}

\author{
Kamil ÇELIK (iD) a Ahmet TAŞ ${ }^{\text {(D) }}$ b \\ a Bartın University, Faculty of Economics and Administrative Sciences, Department of Management Information Systems, Bartın, \\ Turkey. kcelik@bartin.edu.tr \\ b Gümüşhane University Şiran Health Services Vocational School, Department of Pharmacy Services, Gümüşhane, Turkey. \\ ahmettas@gumushane.edu.tr
}

\begin{tabular}{l} 
ARTICLE INFO \\
\hline Keywords: \\
Instagram \\
Consumer Behavior \\
Purchasing \\
Social Media \\
Internet Shopping
\end{tabular}

Received 1 November 2021 Revised 15 December 2021 Accepted 21 December 2021

Article Classification: Research Article

\section{ABSTRACT}

Purpose - The rapid development of technology and the widespread use of digital platforms have led to an increase in online shopping. This study aims to investigate the factors affecting the pre-purchase consumer behavior of individuals who shop on Instagram.

Design/methodology/approach - A questionnaire was distributed to individuals who shopped on Instagram to test the determined hypotheses. The questionnaire was created through Google Forms and the survey link was delivered to the participants via different electronic communication channels. The purpose of the study and by whom it was carried out was stated in the questionnaire. The questionnaire started with demographic questions. And it included scales of pleasure, suitability for lifestyle, informativeness, safety, and pre-purchase consumer behavior. The R program was used to reveal the demographic information and conduct confirmatory factor analysis and structural equation model analysis. SPSS 22 program was used to create the correlation matrix of the scales and to perform the reliability analysis.

Findings - The structural equation model analysis revealed the standard error, $z$-value, $p$-value, Standardized $\beta$ values. As a result of the analysis, all hypotheses were supported. In addition, the $\beta$ coefficients and $\mathrm{R}^{2}$ values among the variables were also examined and it was concluded that prepurchase consumer behavior was explained by pleasure, suitability for lifestyle, informativeness, and safety by $85.5 \%\left(R^{2}=0.855\right)$, and by other variables by $14.5 \%$.

Discussion - It was observed that most of the data obtained as a result of the analyzes supported the relevant literature. However, some findings specific to this study were also obtained. In line with the results of the analysis made in the research, various suggestions have been developed.

\section{INTRODUCTION}

The rapid spread of technology and the increase in the use of digital platforms have led to an increase in shopping activities on the internet. Consumers can perform all stages of shopping in the online environment. Accessing information through digital platforms has become easy for both consumers and producers. Changing lifestyles depending on the development of technology has made it necessary for consumers to use time efficiently. Websites that save time and enable consumers to shop more easily became prominent. Manufacturers develop different shopping methods to meet consumer demands and needs. Sites that employ these methods with internet technologies became a popular trend that differentiates the shopping behaviors of consumers. One of these new channels is Instagram. Instagram became a new shopping medium for many consumers. The number of consumers shopping on Instagram is increasing day by day (Özeltürkay et al., 2017). Today, the increasing use of social media has increased the use of social media businesses. People are affected by communication in social networks and Social media puts the feature of sharing, which is its main purpose, on the second plan (Çelik, 2021).

Social media allows individuals to communicate with anyone they want by establishing interactive communication. The posts of social media users who share their beautiful moments and experiences in their lives can also affect other people's brand perceptions. Producers turn the active use of social media channels into opportunities, engage in activities suitable for people's preferences, and shape consumer behavior. In particular, Instagram's low-cost and very large user base makes it an important promotion and sales channel 
for small businesses. For this reason, small businesses or individual entrepreneurs choose to both promote and sell their products by starting a page on Instagram. Instagram's place among online sales applications is undeniable especially in terms of "consumer-to-consumer" sales. Not only small businesses or individual entrepreneurs but also large businesses use Instagram as a promotional channel and even advertise there (Özeltürkay et al., 2017).

According to We Are Social Digital in 2021 report, 4.2 billion social media users constitute 53\% of the world's population, and this rate has increased by $13.2 \%$ compared to last year. The number of social media users, which was 2.31 billion in 2016, reached 4.2 billion with an increase of $82 \%$ by 2021 . Among the most preferred social media channels, Facebook takes the first place, followed by Youtube and Instagram. While the world average is $44 \%$ in terms of the relationship between social media and e-commerce, one out of every two people using social media in Turkey prefers social media to obtain information about a brand. According to the same report, 1.22 billion users have accessed Instagram ads and the number of female users is higher than that of men. $62 \%$ of the Instagram ad audience is between the ages of $18-34$. The rate of users over the age of 35-44 is $30 \%$. Instagram appeals to the young audience (dijilopedi.com).

Today, businesses that understand the importance of Instagram to reach every segment, every person, at any time, take into account social media and its tools, which are very effective in reaching consumers directly, and use it effectively in their marketing units.

The research is generally aimed at finding answers to the questions of what factors individuals pay attention to before shopping, what are the reasons that push them to shop, and how effective Instagram is in this regard. Thus, the study aims to determine the factors affecting the consumption behaviors of the participants before purchasing. In this way, this study will contribute to the shaping of the marketing strategies of the companies operating on Instagram. Today, where social media and Instagram are used so much, the high potential of Instagram is worth investigating. In this context, it is a matter of curiosity what factors affect the intention of individuals who have shopped on Instagram to continue shopping on Instagram. In this study, the effects of social commerce factors, perceived usefulness, perceived ease of use and trust factors on e-satisfaction and esatisfaction on the intention to continue shopping on Instagram were investigated. Thus, the importance of the research is that businesses make sense of consumer behavior and determine strategies by taking into account the results to be obtained.

\section{CONCEPTUAL FRAMEWORK}

\subsection{Social Media Marketing}

The concept of "social media" is a synthesis of two words, "social" and "media". In this context, social refers to interactions between individuals who have a common interest or belong to a common group and community. Media are channels or platforms that enable user creation and exchange of content (Icha, 2015). Social media applications have had a huge impact on users for the last 15 years. With the increase in the use of social media, the change in the social environment and individuals trying to adapt to it are joining a different new social network every day. This participation can bring about learning, knowledge, and guidance (Zengin and Çakmak, 2019). In addition, by bringing about many concepts such as identities and lifestyles connected to the virtual environment, it causes the wishes and living conditions of users to change (Çalışkan and Mencik, 2015).

Social media allows companies to connect with their customers, raise awareness of their brands, influence consumers' attitudes, get feedback, improve existing products and services, and increase sales (Lal et al., 2020). The exponential growth in the number of Internet users has led businesses to explore efficient ways to manage their electronic presence. Businesses have adopted new business models that enable them to take advantage of the opportunities offered by the internet (Wielki, 2010).

People are spending more and more time online to communicate with other consumers about their experiences, interact with companies, and search for information about products and services. Organizations have responded to this shift in consumer behavior by making digital and social media a core and integral component of their business marketing plans (Stephen, 2016). It is not enough to consider the particular businesses' social media presence or the number of their followers to gain an in-depth understanding of the effectiveness of their actions on social media. How users interact with a business should also be considered. It 
is very important to evaluate the effectiveness of different post types at many stages, from campaign design to theory testing (Coelho et al., 2016).

Social media marketing is a powerful way for businesses of all sizes to reach potential and existing customers. The reasons for businesses to create an identity on their social media platforms are to increase customer loyalty, generate high income, provide customer experience and provide thought leadership. According to Hoffmann and Fodor (2010), among the purposes of the use of social media applications are the fact that businesses' activities on social media applications provide a distinctive feature compared to other businesses and create an advantage in marketing. Having an identity in social media and using these applications effectively has become a necessity for businesses in the changing marketing system. Especially the younger generation makes purchases after checking the information about products and businesses from the applications (Zengin and Serdaroğlu, 2020).

\subsection{Pre-Purchase Consumer Behavior}

Consumer behavior is the activities that are carried out in relation to obtaining, using, and consuming products or services and that include a decision-making process before (Bozkurt and Söyleyici, 2017). Social media sites, which closely affect human life, are effective in consumers' purchasing decisions. Sharing information, videos, criticism, likes, comments, etc. on social media sites has become a driving factor that can affect consumers' decisions (Şener and Yücel, 2020).

Factors affecting consumer behavior can be classified as social factors, psychological factors, personal factors, marketing efforts, and economic factors. Ultimately, consumers' purchasing decision process consists of awareness of the problem, gathering information and identifying alternatives, evaluating alternatives and purchasing decisions behavior (Özcan and Akınc1, 2017). Today, consumers make social media a part of their daily lives, fill their spare time with social media, and are influenced by the content in these channels when purchasing products. It is very meaningful for businesses that social media can affect consumers by being so integrated into daily life. Businesses that aim to understand consumers, be customer-oriented and achieve success in this way have to consider social media and its effects (Yanar and Yllmaz, 2017).

Purchasing behavior forms the basis of consumer behavior. The purchasing stage is a process of purchasing behavior. The main features of consumer behavior are that it is motivated behavior, expresses a dynamic process, deals with different roles, is affected by environmental factors, involves different behaviors for different consumers, is complex, and shows differences in terms of timing. It has a flexible structure as consumer purchasing behavior can change according to time and conditions. Psychological, demographic, and socio-cultural factors greatly change consumer purchasing behavior (Hacialioğlu and Sağlam, 2021).

\section{METHOD}

\subsection{Purpose and Importance of the Research}

Effective communication and marketing methods have been moved to different platforms with the effect of digitalization in the globalizing world. One of these platforms is Instagram. The widespread use of Instagram has made the interaction and communication between consumers and businesses much faster and easier (Şahin et al., 2017). According to the 2020 social media statistics report prepared by We Are Social and Hootsuite, $64 \%$ of the population in Turkey uses social media. The time spent by internet users on social media in Turkey is 3 hours. YouTube is the most used social media platform in Turkey with a $90 \%$ usage rate. It is followed by Instagram with 83\%. 38 million individuals use Instagram in Turkey (Digital 2020 Global Overview Report, 2020). This situation shows the potential and importance of Instagram in product and service marketing (Özdemir et al., 2021).

This study aims to reveal the factors that affect the pre-purchase consumer behavior of individuals who shop on Instagram. It proposes a research model for this. Figure 1 shows the proposed research model. Accordingly, the variables affecting pre-purchase consumer behavior were determined as enjoyment, suitability for lifestyle, informativeness, and trust. 


\subsection{Data Collection Method and Tool}

The data collection technique of the research is the survey technique. The questionnaire, which was prepared by taking into account the previous studies on this subject and by reviewing the necessary literature, was created via Google Forms and the questionnaire link was delivered to the participants through different electronic communication channels. In the questionnaire, first of all, information about the purpose of the study and by whom it was carried out was given. Then, questions about demographic information were asked. Then, the questionnaire consisting of enjoyment, lifestyle, informativeness, safety, and pre-purchase consumer behavior scales was presented to the participants. The obtained data were firstly tested for validity and reliability. Afterward, the data were evaluated with correlation and structural equation modeling, and the findings were interpreted.

In the present study, the questionnaire method was used to collect data. For this, first of all, a literature review was conducted. As a result of the scanning, a new research model has been proposed. The scales of this model have been determined. The original forms of the scales were translated from English to Turkish in two stages. First of all, all the scales were translated into Turkish independently by two academicians and two translation experts who are fluent in English. In the next step, the translations obtained were compared by a researcher and a translation expert, and the translations thought to express the best were accepted. In this state, the scale expressions were given their final form after being checked again by two academicians who are experts in their fields. Based on these scales, a new questionnaire was created. The created questionnaire was first tested with 30 people. As a result of the pre-test, the applicability of the questionnaire was accepted and the online version of the questionnaire was created via Google Forms. The resulting link was delivered to the participants through various social media accounts, forums and blogs. The population of the research is individuals who have shopped on Instagram in Turkey. Snowball sampling method was preferred in sample selection. The participants were asked to spread the questionnaires around them, thus creating a snowball effect. The sample consists of the participants that can be accessed within the scope of the research. As a result, 409 participants were reached.

The scales were prepared by adapting the appropriate scales after the previous studies related to the subject were examined in detail. The answers were obtained on a 5 -point Likert scale ( $1=$ Strongly Disagree, $5=$ Strongly Agree). The lifestyle fit scale was adapted from Chen et al. (2002) and the confidence scale was adapted from Zhou (2013). In order to measure consumer attitudes towards Instagram advertisements, the informative and entertaining dimensions of the scale titled consumer attitudes towards social media advertisements used by Sabuncuoğlu and Gülay (2016) and belonging to Soh et al (2009) and Cheng et al (2009) were adapted to Instagram. In order to measure pre-purchase consumer behavior, the 10-item pre-purchase consumer behavior scales used by İşlek (2012), Şahin et al. (2017) and Özcan and Akıncı (2017) were used.

$\mathrm{R}$ program was used to generate demographic information, confirmatory factor analysis, and structural equation model analysis. The reason for using the $\mathrm{R}$ program is that $\mathrm{R}$ is an open-source, free and user-friendly program (Çelik et al., 2018). SPSS 22 program was used to analyze the correlation matrix and reliability of the scales used.

\subsection{Ethical Aspect of Research}

Before starting the study, an application was made to the Gümüşhane University Ethics Committee by submitting the necessary documents for the research. After the approval of the ethics committee, the questionnaires were distributed. 


\subsection{Research Model, Hypotheses, and Hypothesis Rationales}

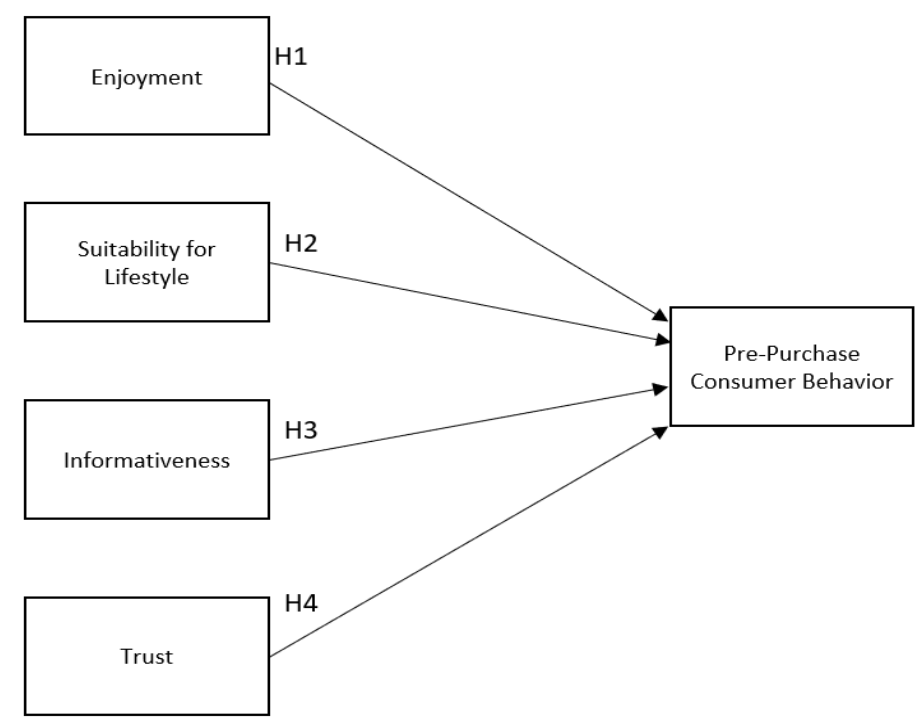

Figure 1. Proposed Research Model

The concept of enjoyment is the degree of happiness or rejoicing for that activity as well as the dedication shown while doing any work (Koçak Alan et al., 2018). The factors affecting the tendency to shop in hedonic consumption are the pleasure and entertainment that individuals feel because of the product they buy. Along with utilitarian values, people also focus on the enjoyable aspects of shopping (Çelik and Taş, 2021). The fact that consumers feel that they enjoy while shopping will affect the increase in their unplanned buying behavior (Akturan, 2010). The expectation to enjoy shopping is a factor that affects online shopping. This should not only be seen as a matter of traditional shopping, but online shopping should also bring pleasure to consumers. The fact that online shopping sites can offer this pleasure is very effective for consumers to turn to internet shopping (Yağc1 et al., 2017). For these reasons, the first hypothesis of the study was determined as follows:

H1: Enjoyment affects pre-purchase consumer behavior significantly and positively.

Consumers who have used online shopping platforms before and are experienced in this field prefer mobile shopping applications. The reason for this is that mobile shopping applications are suitable for the consumer's lifestyle based on the previous internet shopping experiences (Sivanad et al., 2004). Mobile payment methods are compatible with the on-the-go lifestyle, as they offer virtual payment in any situation. Compliance with lifestyle and needs is a determinant of adopting mobile payment methods (Hanafizadeh et al., 2014). The pleasure of shopping is not just about traditional shopping. Consumers also want to enjoy while shopping online. The enjoyment factor has a positive effect on one's shopping. Commerce sites apply different marketing methods to reveal the element of pleasure in online shopping and offer promotions to their customers. In this way, different and fun shopping sites emerge. This makes online shopping enjoyable (Işık and Oz, 2021). In the light of these explanations, the second hypothesis of the research was determined as follows:

H2: Suitability to lifestyle affects pre-purchase consumer behavior significantly and positively.

Production and marketing strategies cannot be successful without considering lifestyles and changes in lifestyles. Consumer behavior can change according to many different parameters. For this reason, it is insufficient to separate consumers only according to demographic and socio-economic characteristics. It is also necessary to pay attention to the general lifestyles of consumers. For example, internal and external factors such as people's past experiences, social and cultural values, emotions and personalities, and the social classes they belong to, cause different consumption behaviors to occur even among individuals of the same age and profession or individuals who grew up in the same culture (Çakmak and Çubukçu, 2020). According to previous studies, the main reason that leads consumers to internet shopping is the ease of access to information about products. Companies that trade on the Internet should have a carefully created digital platform for the ease of access and use of the website (Yağ $\mathrm{Cl}$ et al., 2017). As a result of the development in communication technologies, the ease of accessing information has led to preferring internet shopping over traditional 
shopping. Thanks to this feature, the change and development of e-commerce have accelerated. For such reasons, the third hypothesis of the research was determined as follows:

H3: Informativeness affects pre-purchase consumer behavior significantly and positively.

Trust plays a major role in the overall quality of the website and in arousing customers' impulse to buy (Çelik, 2021). In online shopping, consumers generally have to share their personal information. In this case, the privacy and security rules that ensure trust in preferred websites affect consumer tendencies (Wu et al., 2012). One of the most important reasons that prevent consumers from shopping online or make them hesitate is the lack of trust in the payment system. Account details shared during internet shopping may pose risks to the privacy of individuals' personal information. For this reason, the details of individuals' accounts may fall into the hands of malicious parties (Nazir et al., 2012). Trust plays a central role in managing transactions when shopping online. Lack of trust in online companies is the main reason why many consumers do not shop online (Akçacı and Kurt, 2020). Accordingly, the fourth hypothesis of the research was determined as follows:

H4: Trust affects pre-purchase consumer behavior significantly and positively.

\section{FINDINGS}

The study included 1632 participants ( $N=1632)$. This section presents the findings of the study.

Table 1. Demographic Distribution of Participants

\begin{tabular}{|c|c|c|c|}
\hline & Variables & Frequency & Percentage \\
\hline \multirow[t]{2}{*}{ Gender } & Male & 574 & 35.2 \\
\hline & Female & 1058 & 64.8 \\
\hline \multirow[t]{3}{*}{ Age } & Between 17-24 & 1216 & 74.5 \\
\hline & Between 25-32 & 327 & 20 \\
\hline & 33 or over & 89 & 5.5 \\
\hline \multirow[t]{4}{*}{ Education } & High School & 235 & 14.4 \\
\hline & Associate Degree & 117 & 7.2 \\
\hline & Bachelor's Degree & 1208 & 74 \\
\hline & Postgraduate & 72 & 4.4 \\
\hline \multirow[t]{5}{*}{ Monthly Income } & 0€ & 70 & 4.3 \\
\hline & 1-1000£ & 798 & 47.5 \\
\hline & 1001-3000€ & 444 & 27.2 \\
\hline & 3001-5000€ & 216 & 13.3 \\
\hline & 5001€ or more & 110 & 6.7 \\
\hline \multirow[t]{5}{*}{ Average Instagram usage time per day } & Less than 1 hour & 262 & 16 \\
\hline & Between 1-3 hour & 698 & 42.8 \\
\hline & Between 3-5 hours & 423 & 25.9 \\
\hline & Between 5-7 hours & 144 & 8.8 \\
\hline & 7 hour or over & 105 & 6.5 \\
\hline \multirow{2}{*}{$\begin{array}{l}\text { Usually the preferred communication tool } \\
\text { when using Instagram }\end{array}$} & Mobile Phone & 1581 & 96.8 \\
\hline & Other & 51 & 3.2 \\
\hline Total & & 1632 & 100 \\
\hline
\end{tabular}

Table 1 shows the frequency-percentage distributions of the demographic data of the participants. 35.2\% $(n=574)$ of the participants were male and $64.8 \%(n=1058)$ were female. $74.5 \%(n=1216)$ of the participants were between the ages of $17-24,20 \%(n=327)$ between the ages of $25-32$, and $5.5 \%(n=89) 33$ and over. $14.4 \%(n=235)$ of the participants were high school graduates, $7.2 \%(\mathrm{n}=117)$ associate degree graduates, $74 \%(\mathrm{n}=1208)$ undergraduates, and $4.4 \%(\mathrm{n}=72)$ postgraduates. $4.3 \%(\mathrm{n}=70)$ of the participants haven't income, $47.5 \%(\mathrm{n}=798)$ of the participants have monthly income between 1-1000 TL, 27.2\% $(n=444)$ between 1001-3000 TL, 13.3\% $(n=216)$ between $3001-5000 \mathrm{TL}, 6.7 \%(n=110) 5001 \mathrm{TL}$ or more. $16 \%(n=262)$ of the participants spend less than 1 hour a day on Instagram, $42.8 \%(n=698) 1-3$ hours, $25.9 \%(n=423) 5-7$ hours, and $6.5 \%(n=105) 7$ hours or more.

Table 2. Products purchased by participants on Instagram 
K. Çelik- A. Taş 13/4 (2021) 3821-3834

\begin{tabular}{|l|c|c|}
\hline & Yes & No \\
\hline Clothes & $706(\% 56.7)$ & $926(\% 43.3)$ \\
\hline Shoes & $526(\% 32.2)$ & $1106(\% 67.8)$ \\
\hline Bag & $257(\% 15.7)$ & $1375(\% 84.3)$ \\
\hline Gift of jewelry & $262(\% 16)$ & $1370(\% 84)$ \\
\hline Cosmetic & $240(\% 14.7)$ & $1392(\% 85.3)$ \\
\hline Electronic & $198(\% 12)$ & $1434(\% 88)$ \\
\hline
\end{tabular}

Table 2 shows the products purchased by the participants on Instagram. Accordingly, the participants mostly buy clothes, followed by shoes, jewelry, bags, and cosmetic products. It was determined that electronic products were purchased at least.

Table 3. Goodness of fit values

\begin{tabular}{|l|c|c|c|c|}
\hline Fit index & Value & Good fit values & $\begin{array}{l}\text { Acceptable fit } \\
\text { values }\end{array}$ & Result \\
\hline CFI & 0.948 & $>0.95$ & $>0.90$ & Acceptable \\
\hline RMSEA & 0.065 & $<0.050$ & $<0.080$ & Acceptable \\
\hline TLI & 0.941 & $>0.95$ & $>0.90$ & Acceptable \\
\hline NNFI & 0.941 & $>0.95$ & $>0.90$ & Acceptable \\
\hline NFI & 0.940 & $>0.95$ & $>0.90$ & Acceptable \\
\hline RNI & 0.948 & $>0.95$ & $>0.90$ & Acceptable \\
\hline IFI & 0.948 & $>0.95$ & $>0.90$ & Acceptable \\
\hline
\end{tabular}

The indices of the goodness of fit are Comparative Fit Index (CFI-Comparative Fit Index), Root Mean Square Error of Approximation (RMSEA), TLI Tucker-Lewis Index, Non-normed Fit Index (NNFI), Normed Fit Index (NFI-Normed Fit Index), Relative Noncentrality Index (RNI) and Incremental Fit Index (IFI). Table 3 shows the goodness of fit values of the study. All goodness of fit values shows acceptable fit. This finding indicates that the data is compatible with the proposed model.

Table 4. Cronbach Alpha, AVE, CR, Mean values and correlation matrix

\begin{tabular}{|l|c|c|c|c|c|c|c|c|}
\hline & $\boldsymbol{\alpha}$ & AVE & $\mathbf{C R}$ & $\mathbf{1}$ & $\mathbf{2}$ & $\mathbf{3}$ & $\mathbf{4}$ & $\mathbf{5}$ \\
\hline 1-EN & 0.892 & 0.728 & 0.889 & $(0.853)$ & & & & \\
\hline 2-SL & 0.890 & 0.729 & 0.890 & $0.822^{* *}$ & $(0.853)$ & & & \\
\hline 3-TR & 0.930 & 0.769 & 0.930 & $0.757^{* *}$ & $0.754^{* *}$ & $(0.876)$ & & \\
\hline 4-INF & 0.937 & 0.712 & 0.937 & $0.647^{* *}$ & $0.668^{* *}$ & $0.669^{* *}$ & $(0.843)$ & \\
\hline 5-PPC & 0.937 & 0.600 & 0.937 & $0.732^{* *}$ & $0.746^{* *}$ & $0.731^{* *}$ & $0.821^{* *}$ & $(0.774)$ \\
\hline
\end{tabular}

$\alpha$ : Cronbach Alpha Coefficient; AVE: Average Variance Extracted; CR: Construct Reliability; Values in parentheses are the square root of AVE values; EN: Enjoyment; SL: Suitability for Lifestyle; TR:Trust; INF: Informativeness; PPC: Pre-Purchase Consumer Behavior; ${ }^{* *} \mathrm{p}<0.01$

Table 4 shows the Cronbach Alpha Reliability Coefficient, AVE-Average Variance Extracted, Construct Reliability (CR), and correlation matrix of all scales. Accordingly, the Cronbach Alpha coefficient of all scales took values between 0.890 and 0.937 . The reliability coefficient is acceptable at the level of $70 \%$, and at a good level when it exceeds $80 \%$ (Sekeran, 2003) Thus, the reliability of the scales is quite high.

For convergent validity, AVE is expected to be greater than 0.5 and CR greater than AVE (Hair et al., 2010; Fornell and Larcker, 1981). Table 4 shows that the AVE values are greater than 0.5 . This shows that the validity of the constructs is ensured. In addition, all structures have CR values greater than AVE values. This result shows that the scales are valid. In addition, the discriminant validity of the constructs of the scales was examined. In order to ensure discriminant validity, the square root of the AVE values should be higher than the correlation value of the relevant variable with other variables. Only the correlation value between prepurchase consumer behavior and informativeness is greater than the square root of the AVE value of the relevant scale. Table 3 shows that the square root of the AVE values for each construct is greater than the correlation between the constructs. This result shows that discriminant validity is provided (Hair et al., 2010). 


\section{K. Çelik- A. Taş 13/4 (2021) 3821-3834}

Correlation analysis was performed to show the relationships between variables. According to the analysis, there is a significant $(\mathrm{p}<0.01)$ and positive relationship between all variables. The strongest relationship between the constructs was between enjoyment and suitability for lifestyle $(r=0.822, p<0.01)$, while the weakest relationship was between enjoyment and informativeness $(\mathrm{r}=0.647, \mathrm{p}<0.01)$.

Table 5. Standard error, $\mathrm{z}$ value, $\mathrm{p}$ value and standard factor loads

\begin{tabular}{|c|c|c|c|c|}
\hline & Std.Error & $\mathrm{z}$ & $\mathrm{P}(>|z|)$ & Std. Fac. Loads \\
\hline \multicolumn{5}{|c|}{ Enjoyment } \\
\hline EN1 & 0.028 & 42.743 & 0.000 & 0.861 \\
\hline EN2 & 0.029 & 40.913 & 0.000 & 0.837 \\
\hline EN3 & 0.028 & 42.802 & 0.000 & 0.862 \\
\hline \multicolumn{5}{|l|}{ Trust } \\
\hline TR1 & 0.025 & 43.504 & 0.000 & 0.866 \\
\hline TR2 & 0.024 & 47.339 & 0.000 & 0.911 \\
\hline TR3 & 0.025 & 43.654 & 0.000 & 0.868 \\
\hline TR4 & 0.025 & 43.095 & 0.000 & 0.861 \\
\hline \multicolumn{5}{|c|}{ Suitability for Lifestyle } \\
\hline SL1 & 0.028 & 42.725 & 0.000 & 0.860 \\
\hline SL2 & 0.028 & 42.865 & 0.000 & 0.862 \\
\hline SL3 & 0.028 & 41.050 & 0.000 & 0.839 \\
\hline \multicolumn{5}{|c|}{ Informativeness } \\
\hline INF1 & 0.028 & 40.005 & 0.000 & 0.820 \\
\hline INF2 & 0.027 & 41.313 & 0.000 & 0.837 \\
\hline INF3 & 0.027 & 42.290 & 0.000 & 0.850 \\
\hline INF4 & 0.026 & 43.448 & 0.000 & 0.864 \\
\hline INF5 & 0.026 & 43.792 & 0.000 & 0.868 \\
\hline INF6 & 0.027 & 40.086 & 0.000 & 0.821 \\
\hline \multicolumn{5}{|c|}{ Pre-Purchase Consumer Behavior } \\
\hline PPC1 & 0.030 & 35.279 & 0.000 & 0.752 \\
\hline PPC2 & 0.026 & 39.466 & 0.000 & 0.812 \\
\hline PPC3 & 0.027 & 39.128 & 0.000 & 0.807 \\
\hline PPC4 & 0.026 & 37.747 & 0.000 & 0.788 \\
\hline PPC5 & 0.028 & 33.486 & 0.000 & 0.724 \\
\hline PPC6 & 0.028 & 37.408 & 0.000 & 0.783 \\
\hline PPC7 & 0.028 & 38.530 & 0.000 & 0.799 \\
\hline PPC8 & 0.028 & 36.738 & 0.000 & 0.774 \\
\hline PPC9 & 0.027 & 38.655 & 0.000 & 0.801 \\
\hline PPC10 & 0.030 & 31.883 & 0.000 & 0.699 \\
\hline
\end{tabular}

Table 5 shows the standard error, $\mathrm{z}$ value, $\mathrm{p}$ value and standard factor loads of the items of the scales. Accordingly, TR2 item had the highest factor load with 0.911, and PPC10 item had the lowest factor load with 0.699 . 
K. Çelik- A. Taş 13/4 (2021) 3821-3834

Table 6. Structural Equation Model Analysis

\begin{tabular}{|l|c|c|c|c|c|}
\hline Hypothesis & $\begin{array}{c}\text { Standartd } \\
\text { Error }\end{array}$ & $\begin{array}{c}\mathbf{z} \\
\text { value }\end{array}$ & $\begin{array}{c}\mathbf{p} \\
\text { value }\end{array}$ & $\begin{array}{c}\text { Standardized } \\
\beta\end{array}$ & Support/Rejection \\
\hline $\begin{array}{l}\text { H1: Enjoyment affects pre-purchase } \\
\text { consumer behavior in a meaningful } \\
\text { and positive way. }\end{array}$ & 0.146 & 2.286 & 0.022 & 0.127 & Supported \\
\hline $\begin{array}{l}\text { H2: Suitability to lifestyle affects } \\
\text { pre-purchase consumer behavior in } \\
\text { a meaningful and positive way. }\end{array}$ & 0.151 & 3.498 & 0.000 & 0.201 & Supported \\
\hline $\begin{array}{l}\text { H3: Informativeness affects pre- } \\
\text { purchase consumer behavior in a } \\
\text { meaningful and positive way. }\end{array}$ & 0.076 & 19.798 & 0.000 & 0.577 & Supported \\
\hline $\begin{array}{l}\text { H4: Trust affects pre-purchase } \\
\text { consumer behavior in a meaningful } \\
\text { and positive way. }\end{array}$ & 0.074 & 3.573 & 0.000 & 0.100 & Supported \\
\hline
\end{tabular}

Table 6 shows the standard error, z-value, p-value, Standardized $\beta$, and support and rejection status of the hypotheses obtained as a result of the structural equation model analysis. Accordingly, all hypotheses were supported.

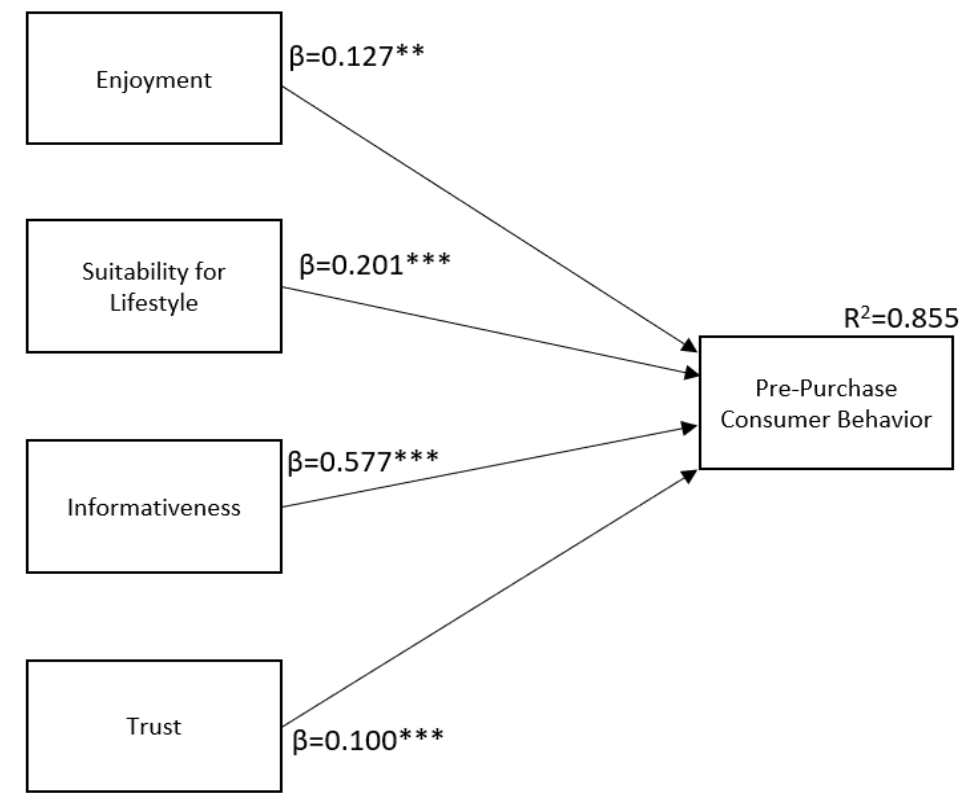

Figure 2. Standardized $\beta$ coefficients and $\mathrm{R}^{2}$ value between constructs, ${ }^{* *} \mathrm{p}<0.05 ;{ }^{* * *} ; \mathrm{p}<0.001$

Figure 2 shows the $\beta$ coefficients and $\mathrm{R}^{2}$ values between the variables. Accordingly, pre-purchase consumer behavior is explained by $85.5 \%\left(R^{2}=0.855\right)$ by enjoyment, suitability for lifestyle, informativeness, and security, and $14.5 \%$ by different variables.

\section{CONCLUSION AND DISCUSSION}

Social media has been used by many people lately. There are different social media platforms used today. One of the social media platforms is Instagram (İnce and Bozyiğit, 2018). Instagram is a social media tool where photos and videos are shared. Thanks to Instagram, users can connect with other users, have the opportunity to express themselves by sharing posts, and thus create a different communication environment. While users have the opportunity to create their own content to express themselves in this environment, businesses can 
also carry out promotion, customer relationship management, marketing, and communication activities for their current and potential target audiences (Şahin et al., 2017).

Due to the uncertainty in consumer behavior, companies have difficulty in performing marketing activities in accordance with the wishes and needs of consumers (Sarıtaş and Karagöz, 2017). Instagram partially eliminates this difficulty and allows businesses to closely monitor the behavior and interests of users (Aprilia and Setiadi, 2017). In this context, Instagram enables researchers to investigate consumer behavior in detail before purchasing.

This study examines the factors affecting pre-purchase consumer behavior. According to the analyses, informativeness is the most effective factor on pre-purchase consumer behavior. This is followed by suitability for lifestyle, enjoyment, and trust factors, respectively.

Informativeness significantly affects pre-purchase consumer behavior. This finding is similar to the findings of the other studies in the literature. Levin and Cross (2004) stated that individuals prefer to refer to people around them rather than documents when they want to get information. Smith et al. (2005) and De Bruyn and Lillien (2008) concluded that information from people they know has a greater impact on consumers' purchasing decisions than information from people they do not know. Ylldiz et al (2013) concluded that the comments, criticisms, and likes made by individuals are effective in consumers' pre-purchase decisions. The study conducted by Sar1 et al (2015) determined that social media users do research on social media about that product/service before purchasing, and they only give importance to the recommendations of people they know before in social media. Aprilia and Setiadi (2017) found that consumers also use Instagram to obtain information before purchasing a product. Özcan and Akıncı (2017) stated that consumers mostly research the product they want to buy on social media before purchasing and they considered the recommendations about the relevant product. Ince and Bozyiğit (2018) stated that before purchasing a product, consumers do research on social media and carefully examine the user comments and features of that product.

Instagram is a unique platform for consumers to express their evaluations of the products they buy, thus facilitating communication. In this way, a person can communicate with many people about the products and the companies that produce these products. In addition to using Instagram as a social media tool, users also see it as the promotional face of businesses. For this reason, businesses that make good use of Instagram achieve remarkable success in the competitive environment. The fact that Instagram offers consumers the opportunity to express their satisfaction, dissatisfaction, or demands about products, to be in direct contact with the business, to get information about a product or service faster and easier shows that Instagram can establish a strong marketing communication network. Thanks to the feedback and comments from Instagram about their goods or services, businesses have the opportunity to innovate or improve their goods or services, gain new customers, retain existing customers, and reflect a positive corporate image. Businesses should actively use Instagram to inform consumers about their products. In addition, they should share the price of the product, detailed product information, and photos with the consumers. Product photos should reflect reality and should be capable of showing all the features of the product. Businesses should create content that will attract the attention of consumers and that they will like, so they should try to increase the rate of appreciation. They should show the satisfaction of existing consumers to other consumers by sharing the customer messages to the business account to report their satisfaction with the product or the photos they take while using the product.

The second most important factor affecting pre-purchase consumer behavior is suitability for lifestyle. Individuals who shop on Instagram closely follow the activities of businesses that fall into their interests. They can visit the Instagram page of the product they will buy, view the images, follow, comment, contact the seller via direct message and review the existing comments. Thanks to these features of Instagram, businesses can manage the pre-purchase behavior of their potential and existing customers with the strategies they will develop.

After businesses sell products to a consumer, if that consumer is satisfied with their shopping, he/she can continue to buy products on Instagram. For this reason, it is necessary to pay attention to the quality of the products, to keep the promises made, and to make the cargo shipments on time in order to satisfy the customer. İnce and Bozyiğit (2018) stated that individuals recommend products they buy or like to each other. They also stated that these positive or negative recommendations are more effective than the activities that businesses 
carry out by paying money. Considering this situation, it is important to ensure that the customer makes a positive comment after purchasing the product, to reduce the factors that can cause negative comments, to consider customers' recommendations, and to help them by contacting them quickly in case of any negative situation. In this way, their satisfaction level should be increased. In addition, customers should be encouraged to make positive comments and to recommend the product to the people they know. In this way, businesses will be able to increase the number of customers and their profitability.

The third factor that affects pre-purchase consumer behavior is enjoyment. In this context, users enjoy shopping on Instagram and find it fun and exciting. In addition, considering that users share the content they enjoy with other users and ensure that the content is spread to the masses, businesses should not neglect the entertainment dimension in their promotions and content of their products. Users who see entertaining content can share this content with their environment and promote the product. Thus, it can increase the number of sales.

The fourth factor affecting pre-purchase consumer behavior is trust. This result is similar to many previous studies. Che et al. (2017) stated that the approval of other users or famous people on Instagram is one of the important factors affecting consumers' trust in Instagram, and the trust factor also affects consumer purchase intention. Aprilia and Setiadi (2017) concluded that consumers determine what to trust and what not to trust on Instagram by paying attention to other consumers' recommendations, the number of followers of the business, and the content design of the profile. Şahin et al (2017) concluded that the trust dimension has the most impact on consumer purchasing behavior. In this context, it is important that Instagram pages keep their promises, establish a quality customer relationship, offer quick and timely solutions in case of problems, protect the rights of their customers and provide support. In addition, it is possible to say that the companies' sales and promotions without confusing the consumers and deceiving them will ensure the trust of the users.

According to the data, the most purchased items on Instagram are clothing, followed by shoes, jewelry, bags, and cosmetics. This finding is similar to the results of the study of Özeltürkay et al. (2017) and İnce and Bozyiğit (2018). The least purchased items are electronic products. The majority of the participants are women (64.8\%) and $74.5 \%$ are between the ages of $17-24$. Especially young and female users frequently buy clothes on Instagram. In this context, it would be a right move for companies operating in the field of textiles to focus on selling activities on Instagram, taking this situation into account. In addition, shoes are the second most sold product (32.2\%). Companies operating in this sector should actively use Instagram. Marketing their products to their customers with both sponsored advertisements and product promotion advertisements has strategic importance.

\section{REFERENCES}

Akçacı, T. and Kurt, F. B. (2020). Online Süpermarket Alışverişinde Tüketici Güven Faktörü. Dicle Üniversitesi İktisadi Ve İdari Bilimler Fakültesi Dergisi, 10(20), 414-433.

Akturan, U. (2010). Hedonik Tüketim Eğiliminin Plansız Satın Alma Eğilimi Üzerindeki Etkisinin Belirlenmesi-Identifying The Effect Of Hedonic Consumption Tendency On Impulsive Buyıng Tendency. Öneri Dergisi, 9(33), 109-116.

Aprilia, A. and Setiadi, B. (2017). Online Buying Decision Process Among Gen Y Instagram Users. International Conference On Psychology And Multiculturalism, 68-73.

Barutçu, S. and Toma, M. (2013). Sürdürülebilir Sosyal Medya Pazarlaması ve Sosyal Medya Pazarlaması Etkinliğinin Ölçümü. Journal of Internet Applications and Management/İnternet Uygulamaları ve Yönetimi Dergisi, 4(1), 5-23.

Bozkurt, Ö. Ç. and Söyleyici, G. T. (2017). Sosyal Medya ve Tüketici Davranışları İlişkisi: Türkiye'deki Sosyal Medya Kullanıcıları Üzerine Bir Araştırma. Kesit Akademi Dergisi, (9), 36-54.

Che, J., Cheung, C. and Thadani, D. (2017). Consumer Purchase Decision In Instagram Stores: The Role Of Consumer Trust, Proceedings Of The 50th Hawaii International Conference On System Sciences, 2017, 24-33.

Chen, L., Gillenson, M. L. and Sherrell, D. L. (2002). Enticing Online Consumers: An Extended Technology Acceptance Perspective. Information and Management, 39(8), 705-719. 
Chen, Y., Fay, S. and Wang, Q. (2011). The Role of Marketing in Social Media: How Online Consumer Reviews Evolve. Journal of Interactive Marketing, 25, 85-94.

Cheng, J., Blankson, C., Wang, E. and Chen, L. (2009). Consumer Attitudes and Interactive Digital Advertising, International Journal Of Advertising, 28(3), 502-525.

Coelho, R. L. F., de Oliveira, D. S., and de Almeida, M. I. S. (2016). Does Social Media Matter For Post Typology? Impact Of Post Content On Facebook And Instagram Metrics. Online Information Review.

Çakmak, D. M. and Çubukçu, M. İ. (2020). Tüketicilerin Hedonik Tüketim Nedenlerinin Yaşam Tarzı Tutumları Açısından İncelenmesi. ETü Sentez İktisadi ve İdari Bilimler Dergisi, (2), 87-120.

Çalışkan, M., and Mencik , Y. (2015). Değişen Dünya'nın Yeni Yüzü: Sosyal Medya. Akademik Bakış Derigisi, 50, 273-283.

Çelik, K. (2021). The Effect of E-Service Quality and After-Sales E-Service Quality On E-Satisfaction, Business and Management Studies: An International Journal, 9(3): 1137-1155, doi: https://doi.org/10.15295/bmij.v9i3.1898

Çelik, K., Özköse, H. and Güleryüz, S. (2018). R ile Yapısal Eşitlik Modeli, Avrasya Sosyal ve Ekonomi Araştırmaları Dergisi, 5(10), 38-48.

Çelik, K. and Taş, A. (2021). E-Ticarette Mobil Alışveriş Uygulamalarını Kullanmaya Devam Etme Niyetinin Araştırılması: Genişletilmiş Teknoloji Kabul Modeli, Üçüncü Sektör Sosyal Ekonomi Dergisi, 56(3), 19972019.

Çelik, K. (2021). Sosyal Ağlar Üzerinden Alışveriş Yapmaya Devam Etme Niyetini Etkileyen Faktörlerin Araştırılması: İnstagram Kullanıcıları Üzerine Bir Araştırma. Sosyal Bilimlerde Güncel Araştırmalar, Astana Yayinlarl, 147-160.

De Bruyn, A. and Lilien, G. L. (2008). A Multi-Stage Model of Word-of-Mouth Influence Through Viral Marketing. International Journal of Research İn Marketing, 25(3), 151-163.

Fornell, C. and Larcker, D. F. (1981). Evaluating Structural Equation Models with Unobservable Variables and Measurement Error. Journal of Marketing Research, Vol:18, No:1, 39-50.

Hacıalioğlu, A. B. and Sağlam, M. (2021). Covid-19 Pandemi Sürecinde Tüketici Davranışları ve E-Ticaretteki Değişimler. Medya ve Kültürel Çalı̧̧malar Dergisi, 3 (1), 16-29.

Hair, J. F., Black, W. C., Babin, B. J. and Anderson, R. E. (2010). Multivariate Data Analysis (7th ed.). Upper Saddle River, NJ: Pearson Education.

Hanafizadeh, P., Behboudi, M., Koshksaray, A. A., and Tabar, M. J. S. (2014). Mobile-Banking Adoption By Iranian Bank Clients. Telematics and informatics, 31(1), 62-78.

https://dijilopedi.com/2021-dunya-internet-sosyal-medya-ve-mobil-kullanim-istatistikleri

Hoffman, D. L., and Fodor, M. (2010). Can You Measure The ROI Of Your Social Media Marketing?. MIT Sloan management review, 52(1), 41.

Icha, O. (2015). Effectiveness Of Social Media Networks As A Strategic Tool For Organizational Marketing Management. J Internet Bank Commer, S2.

Işık, P. and Öz, M. (2021). Online Alışveriş Yapan Süpermarket Tüketicilerinin TüketimTercihlerinin Teknoloji Kabul Modeliyle Açıklanması. OPUS Uluslararası Toplum Araştırmaları Dergisi, 18(Yönetim ve Organizasyon Özel Sayısı), 1-1.

İnce, M. and Bozyiğit, S. (2018). Tüketicilerin Instagram Reklamlarına Karşı Tutumlarının Satın Alma Davranışları Üzerindeki Etkisi: Y ve Z Kuşağı Üzerine Bir Araştırma, Beykoz Akademi Dergisi, 6(2), 3956.

İşlek, M. S., (2012). Sosyal Medyanın Tüketici Davranışlarına Etkileri: Türkiye'deki Sosyal Medya Kullanıcıları Üzerine Bir Araştırma, Yayımlanmamış Yüksek Lisans Tezi, Karaman: Karamanoğlu Mehmetbey Üniversitesi, Sosyal Bilimler Enstitüsü. 
Koçak Alan, A., Kabadayı, E. T., and Erişke, T. (2018). İletişimin Yeni Yüzü: Dijital Pazarlama ve Sosyal Medya Pazarlaması. Elektronik Sosyal Bilimler Dergisi, 17(66), 493-504.

Lal, B., Ismagilova, E., Dwivedi, Y. K., and Kwayu, S. (2020). Return On İnvestment İn Social Media Marketing: Literature Review And Suggestions For Future Research. Digital and Social Media Marketing, 3-17.

Levin, D. Z., and Cross, R. (2004). The Strength of Weak Ties You Can Trust: The Mediating Role of Trust in Effective Knowledge Transfer. Management Science, 50(11), 1477-1490.

Mangold, W. G., and Faulds, D. J. (2009). Social Media: The New Hybrid Element of The Promotion Mix. Business Horizons, 52, 357-365.

Nazir, S., Tayyab, A., Sajid, A., ur Rashid, H., and Javed, I. (2012). How Online Shopping İs Affecting Consumers Buying Behavior In Pakistan?. International Journal of Computer Science Issues (IJCSI), 9(3), 486.

Özcan, B.and Akıncı, Z. (2017). Sosyal Medyanın Üniversite Öğrencilerinin Tüketici Davranışları Üzerinde Etkisi: Turizm Fakültesi Örneği. Süleyman Demirel Üniversitesi Vizyoner Dergisi, 8(18), 141-154.

Özdemir, S., Kayhan, R. and Aksoy Özer, İ. (2021). Pandemi (COVID-19) Döneminde Kaynak Güvenilirliği Boyutlarının, Elektronik Ağızdan Ağıza İletişimin ve Marka İmajı Boyutlarının Tüketici Satın Alma Niyeti Üzerindeki Etkisi: Instagram Fenomenleri Üzerine Bir Araştırma, Pazarlama ve Pazarlama Araştırmaları Dergisi, 14(1), 113-146.

Özeltürkay, E., Bozyiğit, S. and Gülmez, M. (2017). Instagramdan Alışveriş Yapan Tüketicilerin Satın Alma Davranışları: Keşifsel Bir Çalışma. Marmara Öneri Dergisi, 12, s. 175-198.

Perihan, I. and Murat, Ö. Z. (2021). Online Alışveriş Yapan Süpermarket Tüketicilerinin Tüketim Tercihlerinin Teknoloji Kabul Modeliyle Açıklanması. OPUS Uluslararası Toplum Araştırmaları Dergisi, 18(Yönetim ve Organizasyon Özel Sayısı), 1-1.

Sabuncuoğlu, A. and Göker, G. (2016). Sosyal Medyada Görsel Paylaşımından Reklamcılığa: Instagram Reklamlarının Genç Kullanıcılar Üzerine Etkisine Dair Bir Araştırma. Gümüşhane Üniversitesi Sosyal Bilimler Enstitüsü Elektronik Dergisi, 7(15), s.107-131.

Sarı, S., Bozkurt, Ç. Ö. and Kalkan A. (2015). Y Kuşağının Satın Alma Davranışları Üzerinde Sosyal Medyanın Etkisi. 2. Ulusal Yönetim Bilişim Sistemleri Kongresi, (8-10 Ekim 2015), 1(1), 883-897

Sarıtaş, A. and Karagöz, Ş., (2017). Sosyal Medya Kullanımının Tüketici Davranışlarına Etkisi: Üniversite Öğrencileri Örneği, 21. Yüzyılda Ĕ̆itim ve Toplum, 6(17), 359-374.

Sekaran, U. (2003). Research Methods For Business: A Skill-Building Approach (4th ed.). United States of America: John Wiley and Sons, Inc.

Sivanad, C., Geeta, M., and Sulep, M. (2004). Barriers To Mobile Internet Banking Services Adoption: An Empirical Study In Klang Valley Of Malaysia. Internet Business Review, 1(2), 1-17.

Smith, D., Menon, S. and Sivakumar, K. (2005). Online Peer and Editorial Recommendations, Trust, and Choice in Virtual Markets. Journal of Interactive Marketing, 19(3), 15-37.

Soh, H., Leonard R. and Karen, K. (2009). Measuring Trust in Advertising: Development and Validation of The Adtrust Scale,", Journal of Advertising, 38(2), s. 83-103.

Stephen, A. T. (2016). The Role Of Digital And Social Media Marketing In Consumer Behavior. Current opinión in Psychology, 10, 17-21.

Şahin, E., Çağlıyan, V. and Başer, H. H. (2017). Sosyal Medya Pazarlamasının Tüketici Satın Alma Davranışına Etkisi: Selçuk Üniversitesi İ̈BF Örneği, Ömer Halisdemir Üniversitesi İktisadi ve İdari Bilimler Fakültesi Dergisi, 10(4), 67-86.

Şener, A., and Yücel, S. (2020). Sosyal Medyanın Y Kuşağı Satın Alma Davranışları Üzerindeki Etkisi: Bir Literatür İncelemesi. Dumlupinar Üniversitesi Sosyal Bilimler Dergisi, (65), 265-284. 
We Are Social and Hootsuit (2020). Digital 2020 Global Owerview Report, Access Address: https://www.eticaret.gov.tr/static/Pdf/be67689eeccb420e8926b839c7254556_637159836475893573.pdf, Date of Access: 15.08.2021.

Wielki, J. (2010). The impact of the internet on the development of web-based business models. Journal of Internet Banking and Commerce, 15(3), 1-9.

Wu, K.-W., Huang, S. Y., Yen, D. C. and Popova, I. (2012). The Effect of Online Privacy Policy on Consumer Privacy Concern and Trust. Computers in Human Behavior. 28(3), 889-897.

Yağcı, M. İ., Mohamad, E. H. and Doğrul, Ü. (2017). Tüketicilerin Online Alışverişe Karşı Tutumlarını ve Online Alışveriş Yapma Niyetlerini Etkileyen Faktörler: Türkiye-Slovenya Karşılaştırması. Siyaset, Ekonomi ve Yönetim Araştırmaları Dergisi, 5(5), 111-124.

Yanar, K., and Yılmaz, K. G. (2017). Sosyal Medyanın Satın Alma Öncesi Ve Sonrası Tüketici Davranışına Etkisi Üzerine Bir Araştırma. Yönetim, Ekonomi ve Pazarlama Araştırmaları Dergisi, 1(2), 24-40.

Yıldız, Y., Sarıtepe, K.Ö. and Özkaynar K. (2013). Küresel Markalar Savaşında Sosyal Medya Cephesi: Üniversite Öğrencileri Üzerinde Bir Uygulama. Kafkas Üniversitesi İktisadi ve İdari Bilimler Fakültesi 18. Ulusal Pazarlama Kongresi'nde bunulan bildiri. http://acikerisim.aydin.edu.tr/bitstream/11547/1045/2/22-02-2014-10-49-16.pdf\#page=30.

Zengin, B., and Serdaroğlu, Y. (2020). Sosyal Medya Pazarlaması Konusundaki Lisansüstü Tezlerin İçerik Analiziyle Değerlendirilmesi. Gaziantep University Journal of Social Sciences, 19(4), 1562-1579.

Zengin, B. and Çakmak, M. (2019). Sosyal medya kullanımının tüketicilerin yiyecek içecek işletmesi tercihleri etkisi. Diyalektog Ulusal Sosyal Bilimler Dergisi 21, 243-256.

Zhou, T. (2013). An empirical examination of continuance intention of mobile payment services. Decision Support Systems, 54, 1085-1091. 